\title{
Improving Students' Learning Outcomes In Mathematics Educational Research Course By Using Project Based Instruction
}

\author{
Nila Kesumawati \\ Department of Mathematics Education, PGRI University of Palembang \\ Jl A. Yani Lrg. Gotong Royong, 9/10 Ulu Plaju Palembang, Indonesia \\ e-mail: nilakesumawati@yahoo.com
}

\begin{abstract}
This classroom action research was done in Mathematics educational departement of PGRI university of Palembang. Based on my observation during three years, the students were low on searching journals and they were less motivation on reading related to the research variables. The focus was aimed at improving the achievement of students' learning outcomes by using project based instruction in Mathematics educational research course. The learning outcomes were described in the ability of understanding the basic concepts of educational research; the ability to create a research proposal; and presenting a research project proposal. Data were analyzed by comparing students' grade with the minimum passing grade was 70 . The research was carried out for two cycles. The results obtained indicate that the mean score reached the minimum requirement. The students also understood how to produce better of background of the problem; formulate a problem; understanding of the literature; and how to produce a correct hypotheses.
\end{abstract}

Keywords: Project Based Instruction, Mathematics Educational Research Course, Mathematics Educational Departement, PGRI University of Palembang

\section{Introduction}

Most of the sixth semester students of FKIP Universitas PGRI Palembang felt that they have not mastered the basic concepts of research, and some have less awareness that the importance of reading research results from national journals and international journals. This shows the initial symptoms from the initial assignment given to the 33 students, the 29 students (88\%) did not master the characteristics of the problem and how to formulate good problems, the purpose of literature study, and also did not master the use of information technology (IT).

Based on my observation since three years, the students are lack of motivation to read both national and international journals. Students were not accustomed to understand the basic concepts of research, such as explain what the problem is; explain what is meant by literature study; how to make a good formulation problem; purpose of the study of literature; describe the characteristics of a good hypothesis; write assumptionsbefore the hypothesis is formulated;and what is the definition of the basic assumption.

Here was one example of student's error in making research proposal.

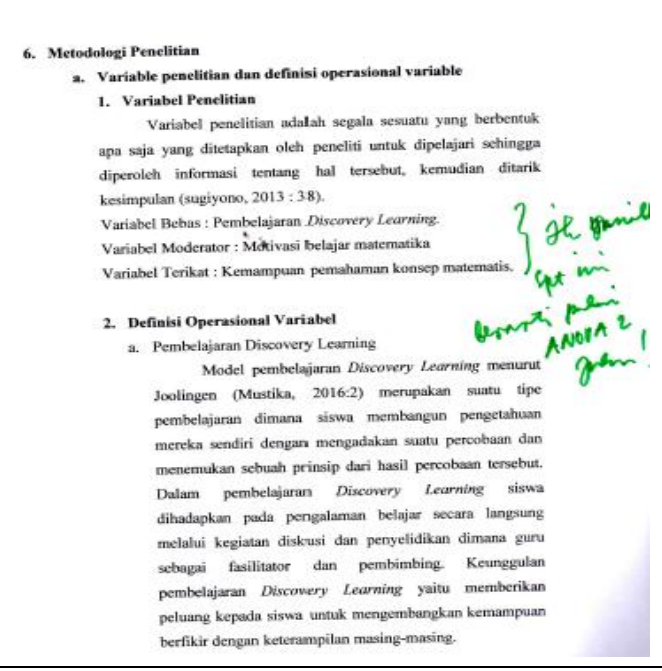

DOI: $10.9790 / 0837-2205081015$

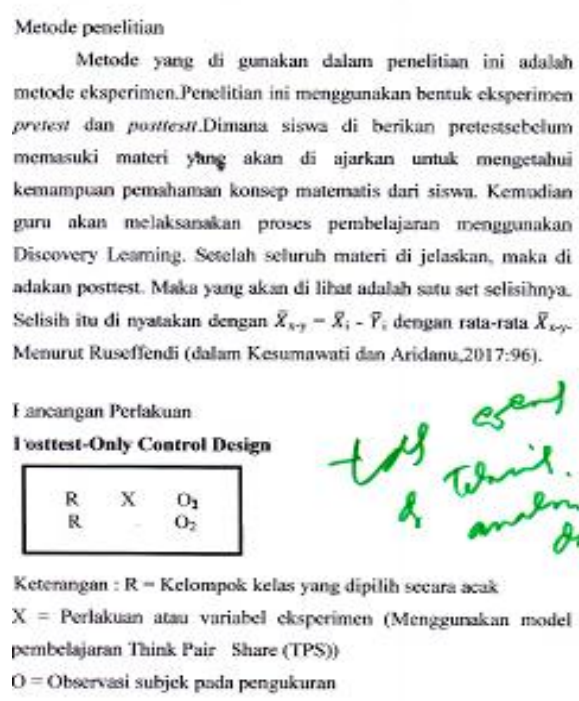

Keterangan : R - Kelompok kelas yang dipilith seeara asek

$\mathrm{X}=$ Perlakuan atau variabel elsperimen (Menggunakan model pembelajaran Think Pair Share (TPS))

$\mathrm{O}=$ Observasi subjek poda pengukuran 


\section{Figure 1}

Figure 2

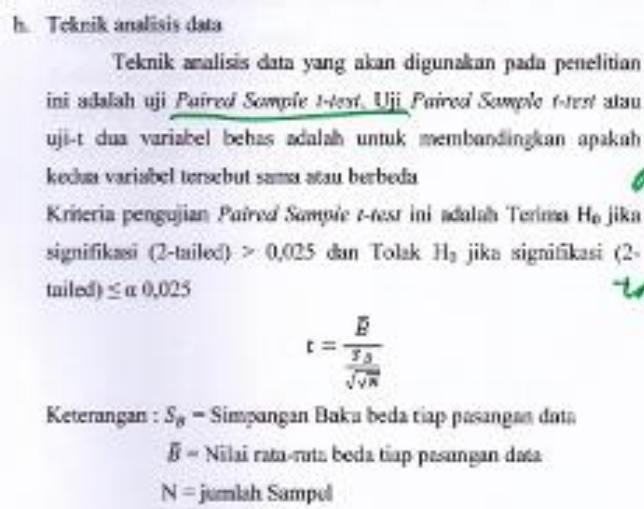

Figure 3

Based on the above problems the lecturer of Mathematics Education Research must have a carefulness to choose approach of lecturing that can invite student to actively participate in lecture of Mathematics Education Research.Simultaneously can encourage students to be able to understand the basic concepts of research; capable on generating research ideas; able to develop a research proposal; note the research data; analyze the data; and skillfully prepare research report [1].

Lecturers have a role on the success of the lecture. Accuracy and ability lecturer in determining and applying the method in accordance with the lecture courses will affect the achievement of the thoroughness of students' results and students' activity upper division courses. According to [2] the characteristicsof the methodhas advantages and disadvantages which require educators to be able to use a variety of learning methods.

There are many methods of learning, lecturers should be able to choose which method is suitable for learning. The low quality of learning can be caused by many factors (a) the differences in backgrounds and learning styles of students, (b) the learning process which tends to be verbal, and (c) the preconceptions on the minds of learners in interpreting natural phenomena [3].

Based on the above phenomena, the Project Based Instruction is the solution to achieve competency courses. This study was improving students' learning outcomes in mathematics educational research course by using project based instruction. Project Based Instruction had been selected as a model lecture, due to the steps of learning to achieve certain learning through a project within a certain time period [4] by going the steps (a) preparation/planning, (b) implementation, (c) preparing reports, and (d) communicating the results of activities [5].

According to [6], [7], [8] Project Based Instruction is an instructional model that facilitates authentic student in planning, implementing, reporting and evaluating projects. Students are encouraged to produce a proposal paper which exercise students to solve problems in the final project. According to[9]steps of Project Based Instruction have six steps are (1) identify and define the project; (2) search for information; (3) planning the project; (4) implement the project; (5) document and report the discovery; and (6) evaluation the project. Slightly different from the syntax-based mathematics curriculum project 2013 which start with the essential question; design a plan for the project; create a schedule, monitor the student and the progress of the project; assess the outcome; and evaluate the experience [10].

According to[11] Project Based Instruction has characteristics (a) learners make decisions about a framework; (b) the problems or challenges posed to the learner (c) learners design a process to determine a solution to the problems or challenges posed (d) learners collaboratively responsible for accessing and managing information to solve the problem (e) the evaluation process is run continuously (f) the participants periodically reflect the activities that have been carried out $(\mathrm{g})$ the end product of learning activity will be evaluated qualitatively and (h) a learning situation is very tolerant to errors and changes. Therefore, the lecture of Mathematics Education Research by using Project Based Instruction facilitate students to design, implement, report a research project as well as evaluating the study results.

Related to the research project proposal, students practice making a good background of the problem, identify problems with the formulation of the research problem, literature, formulating hypotheses, designing research, collecting data, analyzing data, drawing conclusions, presented its findings, as well as writing research reports. [9] States a project-based instruction can improve students' ability to plan and carry out research and communicate the results of research. From these results, project-based instruction will carry students to develop 
creative ideas in solving problems. The project-based instruction is also motivate students to be more active and initiative to obtain either the knowledge, understanding or skills.

In line with the above, educational goals are classified into three categories, is the skill of thinking, behavior, and physical skills that represent the three domains of education domain is cognitive, affective, and psychomotor [12]; [13]; and [14]. So also is listed in the 2013 curriculum, educational goals realized by the mastery of competence of learners on aspects of attitude, knowledge, and skills. In the assessment of the learning process assessment activities can not stand alone.For example, to produce a project that is preparing a research proposal, students should have knowledge or understanding of basic research, has a response to the task (attitude), and have the skills to develop a research proposal.

The implementation project-based instruction in this study had five stages of learning adapted from [9]; [10]; and [15]. Phase one (essential question), in this phase, students discuss the basic concepts of mathematics education research. Students in groups which consist of 4-5 person determine the basic concepts of the research. The lecturer suggests essential questions to discover knowledge that has been owned by the students based on their learning experiences that lead to the assignment.Phase two (designing the project planning), lecturer facilitate each group to determine democratically chairman and secretary, and describe each task. The students discuss about the rules agreed upon in the process of completion the project. Phase three (looking for information), after obtaining problem that will be investigated, lecturer assign individual students seeking books, national journals, and international journals related to the problems. After the literary collected then analyzed and discussed in groups, students select the information that can be used to support the project. Lecturer guide and facilitate student to select appropriate information and perform critical analysis of the information obtained in order to be useful for the planning and implementation of projects.

Phase four (implementing projects and monitoring the progress of the project), the students carry out a project based on the planning that has been compiled. Collect documents and process them to realize part by part until the final product produced. Lecturer facilitate students in making reports the ongoing process of project tasks and communicating obstacles in doing the project as a form of reflection in the learning activities. Phase five (communicating project), students presented the results of project in class to obtain feedback from other students and lecturer. The lecturers guide students to present the results properly as well as to report the discussion project. This research aimed at improving students' understanding of the basic concepts of research, improving students' ability in designing the research and research proposal, and improving students' ability to communicate the research design.

\section{Methods}

This research belongs to a Classroom Action Research. The classroom action research has a very important role to improve the quality of learning [16]; [17]; [18].The materials in this study were books, journals, computer, and infocus. This research was conducted in two cycles. Each cycle consists of four phases were planning, actuating, observing, and reflecting. This research focused on one class in Mathematics Education Courses semester VI.B in the academic year 2016/2017. The course materials were Mathematics Education Research up to the midterm which consist of understanding the basic concepts of mathematics education research, preparation of research proposals, communicating research proposals through classroom seminars.

The collecting data in this study was using test understanding of the basic concepts of the study, proposal assessment rubrics and assessment rubrics observations during lectures. Data were collected during the study and the instrument used was the enforceability of lectures and learning outcomes in the form of understanding of the basic concepts of research, learning outcomes in the form of project proposal writing, and learning outcomes in the form of communicating project outcomes research proposal). The learning outcome data were analyzed to increase students' results.Data were analyzed by means of lectures to see if the course has been implemented according to the courses plan were made. Data improvement of learning outcomes in the form of understanding the basic concepts of the study was obtained from the results of tests on the cycle I and the cycle II. The limitation was students' understanding of basic concepts of research equal to or greater than the minimum score 70. The success of the understanding the basic concepts of research based on the improvement on the first cycle and the second cycle. The success of the action in the preparation of research proposals and communicating the research proposal by imrovement the test results of the first cycle and the second cycle. Students master drafting research proposals and communicate the research proposal if the students get score equal to or greater than the minimum score 70 .

\section{Results}

The Implementation of project-based instruction in this study was to improve the understanding of the basic concepts of research, improve proposal preparation, and improve the rule of communication the research proposal in seminar class. The results werefirst, understanding the basic concepts of the study was measured 
through tests understanding of the concept and the task group.Test material was the research problem, the characteristics of a good problem, literature review, research hypothesis, data collection, data analysis techniques, bibliography, research design, population and sample. The test results of understanding the basic concepts of the study in the cycle I, the mean was 60.75 lower than the minimum score 70 . Data showed that only 9 students $(27.27 \%)$ who got greater than or equal to 70 . This means understanding the concept of student research is still less than the minimum score.

In the cycle II, the lectures was modified by assigning the task group as a project to improve the understanding of the basic concepts of student research.The task of the group in the form of questions were worked together in groups outside the class hours. The task was discussed in the group. In the cycle II the score of understanding the basic concepts of research was improved, the average score obtained was 69.41. The average score approached the minimum score. The students who achieve the minimum score were 22 students (66.67\%). Students work on the task group on the cycle II to strengthen the ability of understanding basic concepts of research. At the time execution of the task group, the students were given a sheet assessment of group reports.Group reports systematic of assessment sheet reports, report completeness, clarity and regularity of writing, the truth of the concept ideas presented, the ability of students to explain the content of the report. The mean of the group is 75. Data reporting cycle I and II can be seen in Table 1 below.

Table1. Score of Understanding Basic Concepts Research

\begin{tabular}{|l|l|l|l|}
\hline Score & $\begin{array}{l}\text { Understanding the Basic } \\
\text { Concept of Research } \\
\text { (Cycle I) }\end{array}$ & $\begin{array}{l}\text { Understanding the Basic } \\
\text { Concept of Research } \\
\text { (cycle II) }\end{array}$ & $\begin{array}{l}\text { Group task } \\
\text { Understanding the Basic Concept of } \\
\text { Research (Cycle II) }\end{array}$ \\
\hline Mean & 60,75 & 69,41 & 75 \\
\hline The Highest Score & 80,95 & 85,71 & 85 \\
\hline The Lowest Score & 28,6 & 35,71 & 70 \\
\hline$\%$ Minimum Reaching (70) & $27,27 \%$ & $66,67 \%$ & $100 \%$ \\
\hline
\end{tabular}

The mean of the test understanding the basic concepts of this study was lower when compared to the score of the task group on understanding the basic concepts in the second cycle. Students work on the task group based on the assessment sheet the group's report has been informed by the lecturer to student. The task group given requires students to be able to think creatively justify fundamental things about the prerequisite knowledge in the preparation of the proposal.

Second, (ability to prepare proposals), ability in preparing the research proposal was measured through evaluation sheets research proposal.In the cycle I, students in groups were given the task to develop a research proposal. Proposal development studies were conducted with a view to determine the ability of students to develop a research proposal. In preparing the research proposal consist of background and research questions, the benefits and contributions of research, the literature review, the theoretical basis and conceptual framework, research methodology, expected results, and the proposal.

The assessment result is the ability to create research proposals 73.77 ; look that is higher than the score of the minimum score 70. As many as one group of students (69.14) which is less than the minimum score, while the other seven groups of students who scored more than minimum. In the cycle II students were tasked to enhance the proposal that has been structured in a manner to critically analyze the results of the class discussion that has been corrected by the other groups and also by lecturers.

Furthermore, as a group of students improve their group proposal. Proposals that have been repaired reassembled to get ratings. Data score of the proposal which had been repaired obtained average score was 78.78 and $100 \%$ of proposals student groups already exceeded the score of the minimum 70 . The improvement in the normalized (n-gain) score proposal is the group in the low 0.19 based on criteria. Third, communicate the research proposal in the seminar class. At the presenting time, the research proposal assessment, the assessment carried out in the cycle II. Proposals that have been corrected which presented in class discussion consist of 1) presentation ability were presentation, systematic presentation, the use of standard spoken language, and timeliness; 2) question and answer were correctness and accuracy of the answers, how to answer, and 3) openness presenters in a question and answer werecooperation, conclusions, and closing. Preparation of research proposals made during the 3-4 weeks). The mean of the results presentation seminar class proposal is 80.45 . Average of this score is higher than the minimum score, and also the score of all groups on the score minimum 70. Data cycle I and II can be seen in table 2 below.

Table 2. The Score of Proposal and Seminar Proposal

\begin{tabular}{llll}
\hline Score & Research Proposal Cycle I & Research Proposal Cycle II & Seminar Proposal \\
\hline Mean & 73.77 & 78.78 & 80.45 \\
The Highest Score & 7.42 & 81.43 & 95 \\
The Lowest Score & 69.14 & 74.14 & 70 \\
\% Minimum Reaching (70) & $87.5 \%$ & $100 \%$ & $100 \%$ \\
\hline
\end{tabular}


Reflection of the test results showed that the understanding of the basic concepts of the study in the first cycle was still low compared to the minimum score.Based on these results researchers modified the lecture by giving the task of basic concepts of research done by the students in the group, the number of members of a group were 3-4 students. Tasks that have been done in group of students outside the lecture was collected and then discussed in class. The modification of the lecture then in the second cycle of understanding the basic concepts of research has improved from 60.75 into 69.41 although the average score was still below the minimum score. Based on these, they pursued another strategy lectures to increase understanding of the basic concepts of students, for example by giving examples relevant to the basic concepts of research or faculty give back annotation associated with material that has not been mastered by students

The average score of the research proposal was 73.77 higher than the minimum 70 . From these data indicate 7 groups of $87 \%$ exceeds the minimum score. In the second cycle, students improve and supplement the proposal to be more creative in the writing background, the formulation of the problem, hypothesis, the hypothesis criteria, as well as data analysis techniques. The students were asked to find a reference as a source of support for research. The average score of research proposal on the second cycle group obtained 78.78 and $100 \%$ have exceeded minimum standard.

The mean of presentation during a seminar in class is 80.45 . The mean of this score is higher than the minimum score. The presentation of the data in this group showed that all students have the presentation skills more than the minimum standard.

\section{Discussion}

The research result showed that the implementation of project-based learning can improve students' ability in understanding the basic concepts of the study even if the increase is included in the low category. It also showed that the increase of students' understanding of the concept was still below the minimum score 75 [9].Project-based instruction was an instructional model that watched students understanding in exploration, appraisal, interpretation, and synthesize information through a meaningful way [19].

In the understanding of the basic concepts of study, students examine how to look for information to support the background so that it can formulate the research problem, reviewing the relevant theory and research in order to disclose the research hypothesis, the hypothesis associated with students' research can determine the data analysis techniques.Appropriately carried out project-based instruction for learning model that focuses on the concepts and principles of a discipline central, involving students in problem-solving activities and tasks that are meaningful, in the end products or works of learners [20].

In addition, the results of this study indicate that the implementation of project-based learning can improve students' ability in groups in preparing the research proposal and present it in a seminar held in the classroom. The results are consistent with research conducted [21] which also showed an increase in the ability to write scientific papers with the implementation of project-based learning. Student success in mastering the competency courses of mathematics education research is inseparable from project-based collaborative learning. The project results were displayed in the form of student mathematics education research proposals that have been seminarized in class. From the results of the seminar were seen that students were more critical in asking and responding to questions.

This is in line with the results of research which states the project-based instruction help students think critically; critical thinking is the ability to think logically involves the ability to compare, classify, create causality, deductive and inductive thinking, designing, hypothesize, and give criticism. Project-based instruction has an authentic score in education in guiding learners to plan or develop a research proposal and present a research proposal by the intention of communicating the research plan. Students learn responsibility through the presentation of research proposal and analysis the literature [9]. At the presentation time of the research proposal, students learn to accept criticism and advice, develop the skills of rational thinking, providing a logical reason, and learning to accept the weaknesses and strengths [9].

\section{Conclusion}

Project-based instruction gave students the opportunity to develop the ability of understanding basic concepts of research, develop a research proposal and communicate the research proposal. Project-based instruction was able to improve understanding of the basic concepts of research through group work. Students were also understand how to make the background with a better problem; formulating the problem; understanding literature review; and how to generate the correct hypothesis. Project-based instruction was also able to improve students' ability to develop a research proposal and communicate the proposals through seminars proposal. The average score obtained by students has exceeded the minimum score 70 . In the first cycle the percentage of students who have achieved a minimum score was $87.5 \%$; and the second cycle was $100 \%$ of the students who have achieved minimum score. Researchers recommend the use of project-based instruction for other suitable subjects such as statistics; the use of project-based instruction model consider the 
suitability of the material and the ability of learners to think; the ability of learners in designing a project, learners are accustomed to work independently and confidently.

\section{Acknowlegment}

The authors thank to the PGRI University of Palembang, due to the funding of DIPA-2017 for this work.

\section{References}

[1]. FKIP Universitas PGRI Palembang. (2006). Educational Curriculum of Mathematics. 105.

[2]. Djamarah, Syaiful Bahri. (2000). Teacher and Learner on Educational Interactive. Jakarta: Rineka Cipta.

[3]. Hood, Karen. (2004). Exploring Learning Styles and Instruction. The University of Georgia, Department of Mathematics Eucation. (online). http://jwilson.coe.uga.edu/emt705/EMT705.Hood.html.

[4]. Sastrika, et.al. (2013). E-Journal Program Pascasarjana Universitas Pendidikan Ganesha. (e-journal.undiksha. ac.id/index. php/JJPBS/ article). 3

[5]. Purworini, Stevani Endah. (2006). Project Based Learning on Developing Habit of Mind, Case Study in SMP Nasional KPS Balik Papan. Jurnal Pendidikan Inovatif, Vol 1 No.2: 17-19. https://jurnaljpi.files.wordpress.com/.../vol-1-no-2-stevani-endah-p.

[6]. Railsback, J. (2002). Project-based instruction: Creating Excitement for Learning. Northwest Regional Educational Laboratory, (Online), http://educationnorthwest.org/sites/ default/files/projectbased.pdf. 6-7.

[7]. Colley, K. (2008). Project-Based Sciences Instuction. The Sciences Teacher, 75(8): 23-28.

[8]. Baidowi, et.al. (2015). Jurnal Pendidikan Geografi,. 20(1). (http:download,portalgaruda.org/artcle.php)

[9]. Suwono, Hadi. (2012). The Implementation of Project Based Learning to Improve the Students' Achievement on Reseach Methodology Course. Jurnal Ilmu Pendidikan. 18(2), 157-165.

[10]. Kemendikbud. (2013). The Material on Training Teachers for the Implementaion of Curriculum 2013. BPSDMPK and PMP.

[11]. Faiq, Muhamad. (2015). The Project Based Learning and Curriculum 2013 for Teachers, Students and The Candidate Teachers. (online). http://penelitiantindakankelas.blogspot.co.id /2014/05/model-pembelajaran-project-based.html.

[12]. Endrayanto and Harumurti. (2014). The Students' Assessment in School. Yogyakarta: Kanisius. 32-33.

[13]. Susanto, Ahmad. (2016). Learning Theory and Instruction. Jakarta: Prenadamedia. 6 - 7.

[14]. Djiwandono, SEW. (2009). Educational Psychology. Jakarta: Gramedia. 218 - 220.

[15]. Warsono and Hariyanto. (2016). Active Learning. Bandung: Remaja Rosdakarya. 156-157.

[16]. Kusnandar. (2010). Classroom Action Research. Jakarta: Raja Grafindo.

[17]. Wiriaatmadja, Rochiati. (2008). Classroom Action Research Methodology. Bandung: PT Remaja Rosdakarya. 44-49.

[18]. Susilo. (2007). Classroom Action Research. Yogyakarta: Pustaka Book Publisher. 18.

[19]. Fathurrohman, Muhammad. (2015). The Innovative Learning Models. Jakarta: Ar-Ruzz Media. 120.

[20]. Ngalimun, et.al. (2015). The Strategy and Learning Model. Yogyakarta: Aswaja Pressindo. 187-189.

[21]. Turyantana, I. Ketut. (2013). The Implementation of Project Based Learning Model to Improve the Students' Activity and Passing Grade of Learning Achievement of Scientific Works Grade XI IPS 1 SMA Saraswati Seririt. (online). ejournal.undiksha.ac.id/index.php/JJPBS/article/view/363.5, (2013). 